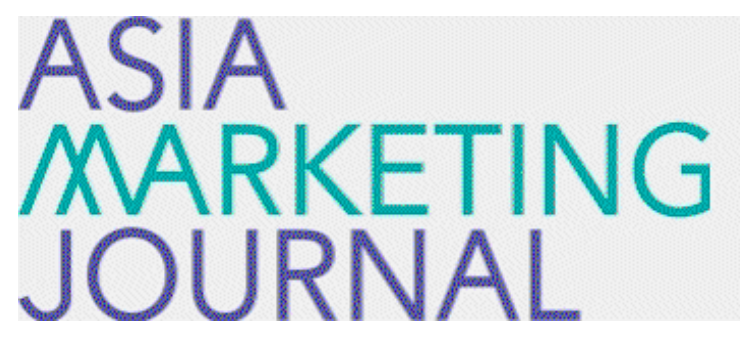

ASIA MARKETING JOURNAL

Volume 21

Issue 2 01/01/2019

Article 6

7-31-2019

\title{
ASIA MARKETING JOURNAL Vol.21 No.2 목차
}

Follow this and additional works at: https://amj.kma.re.kr/journal

Part of the Marketing Commons

\section{Recommended Citation}

(2019) "ASIA MARKETING JOURNAL Vol.21 No.2 목차," Asia Marketing Journal: Vol. 21 : Iss. 2 , Article 6. Available at: https://doi.org/10.53728/2765-6500.1337

This Article is brought to you for free and open access by Asia Marketing Journal. It has been accepted for inclusion in Asia Marketing Journal by an authorized editor of Asia Marketing Journal. 


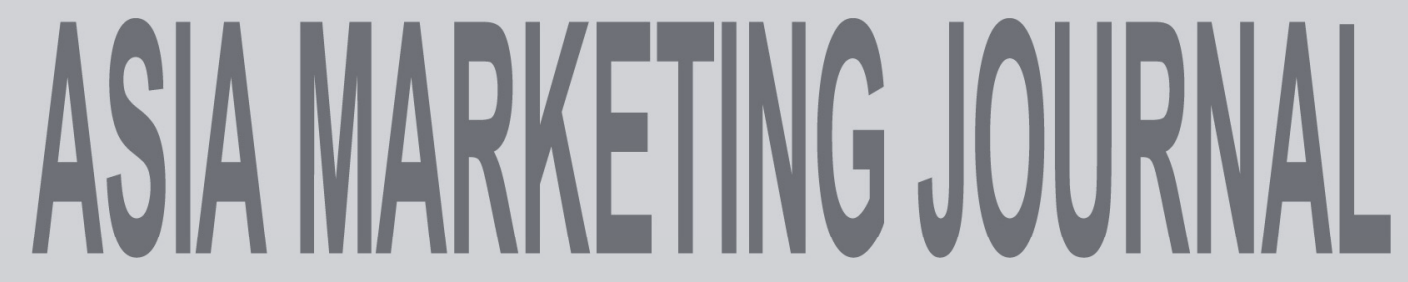

\section{Vol. 21 No. 02 July 2019}

\section{<Research Paper>}

The Effects of One-Sided vs. Two-Sided Review Valence on Electronic Word of Mouth (e-WOM): The Moderating Role of Sponsorship Presence

The Study on the Effect of Waiting Line on Consumers' Perceived Quality and Emotional State Nan Li · Jae-Do Song

\section{$<$ Case Study>}

Globalizing the MEDIHEAL Brand: L\&P Cosmetic's Collaboration with BTS

\section{<Research Paper>}

Effect of Online Word of Mouth on Product Sales:

Focusing on Communication-Channel Characteristics

Luxury Brand Equity in Online Channel: The Moderating Effect of Brand Trust 